\title{
The Use of Polypropylene Mesh in the Reconstruction Techniques of the Thoracic Wall After Resections of the Thoracic Wall
}

\author{
BOGDAN ANDREI SUCIU ${ }^{1,2}$, IOANA HALMACIU1*, VASILE BUD², CONSTANTIN COPOTOIU ${ }^{2}$, \\ DECEBAL FODOR ${ }^{1,2}$, CRISTIAN TRAMBITAS ${ }^{1}$, DUMITRU GODJ $A^{2}$, VLAD VUNVULEA ${ }^{1}$, CALIN MOLNAR ${ }^{2}$, KLARA BRINZANIUC ${ }^{1}$ \\ UUniversity of Medicine and Pharmacy,Anatomy Department, 38 Gheorghe Marinescu Str., 540142, Tirgu Mures, Romania \\ 2 Surgery Clinic no. 1 Mures County Emergency Clinical Hospital, 50 Gheorghe Marinescu Str., 540136, Tirgu Mures, Romania
}

\begin{abstract}
The thoracic wall resections for tumoral affections are laborious surgical interventions characterized by a high mortality and mobility. In order to create this paper we created a observational retrospective study in which we included 21 patients that have underwent parietal thoracic resections for tumoral affections. In all the patients we practiced the reconstruction of the thoracic wall using polypropylene mesh. The main postoperative complications were: seromas (14.28\% of the cases), hematomas (9.52\% of the cases), wound infection (4.76\% of the cases), pneumonia (23.8\% of the cases), respiratory failure $(23.8 \%$ of the cases), paradoxical movement of the thoracic wall (52.38\% of the cases). No deceases were recorded. In conclusion, the use of polypropylene mesh in the reconstructive techniques of the thoracic wall after thoracic wall resection represents a viable method, with good respiratory functional results.
\end{abstract}

Keywords: polypropylene, thoracic wall resection

Often, in clinical practice, after surgical resections of the thoracic wall for tumor formations, parietal defects occur which need various surgical reconstruction techniques of the thoracic wall. Most commonly, these surgical interventions are practiced for primary tumors or metastasis of the thoracic wall or for lung tumors that invade the chest wall, being a known fact that lung tumors are usually aggressive and frequently invade the surrounding structures $[1,2]$. Surgery to reconstruct the thoracic wall after thoracic parietal resections are extensive interventions with a rather high morbidity, which can reach up to $60 \%$ of the cases. The main postoperative complications that may occur in these patients are: respiratory failure, paradoxical movements of the chest wall, chronic pain or thoracic wall suppuration $[3,4]$. There is currently no unanimously accepted agreement on surgical techniques and alloplastic materials used in thoracic wall reconstruction surgery [5]. At the moment plastic meshes are used for the replacement of thoracic or abdominal parietal defects [6].

\section{Experimental part}

In order to accomplish the present paper, we carried out a retrospective observational study for a period of 6 years between 1.10.2011 and 1.10.2017. In this regard, we used the case database of the Surgery Clinic no. 1 from the MureCounty Emergency Clinical Hospital. We included in this study 21 patients with thoracic tumour formations in which chest parietal resections have been performed. Necessary data from the study was obtained from patients' observation sheets and from the study of operator protocols. The statistical analysis of the data was done using the Microsoft Excel software.

As the selection criteria for the inclusion of patients in the study, we only used patients with the diagnosis of thoracic parietal tumors in which thoracic wall resection was practiced and at least four ribs were resected in the anterolateral wall. Also, in all these patients, reconstruction of the thoracic wall with polypropylene mesh was performed. Clinical-pathological characteristics of patients under study are presented in the table 1.

Regarding the histopathological type of the resected tumors, 7 cases were pulmonary malignant tumors that invaded the thoracic wall, and besides the resection of the thoracic wall, pulmonary resections were performed. The benign chest wall tumors were represented by enchondroma and the malignant by condrosarcoma.

Regarding the surgical technique, we used posterolateral thoracotomy as a pathway. All of the patients had tumors located in the anterolateral wall. The resection of the thoracic wall has been performed within the limits of oncological safety, in the sense that a coast below and above the boundary of the tumor formation has been dissected.

Reconstruction of the thoracic wall was performed using polypropylene mesh. The mesh was fixed at the edges of the parietal defect with isolated vycril (bioresorbable material) that had been passed trough the intercostal spaces. After suturing the mesh at the limits of the parietal defect, we sutured in the anatomical planes the overlying muscular planes.

The postoperative complications registered in the group studied by us are presented in figure 4 . Thus, in the studied group we recorded 3 cases of postoperative seromas at the site of implantation of the polypropylene mesh (14.28\% of cases), 2 cases of postoperative hematomas $(9.52 \%$ of cases), 5 cases of pneumonia ( $23.80 \%$ of cases) 1 case of thoracic wall plasty infection (4.76\% of cases), 5 cases showed respiratory failure phenomena ( $23.80 \%$ of cases) and 7 patients presented paradoxical movements of the thoracic wall (52.38\% of the cases). We did not record deceases in the lot we studied.

In the case of postoperative seromas and hematomas, the conservative treatment was chosen, none of the patients required surgical reintervention. The patient who presented the postoperative wound infection was

\footnotetext{
*email: anca_halmaciu@yahoo.com; Phone: 0040740091324
} 


\begin{tabular}{|c|c|c|c|}
\hline & & Number of cases & Percentages \\
\hline \multicolumn{2}{|l|}{ Age } & $45-63$ ani & \\
\hline \multicolumn{4}{|c|}{ Gender } \\
\hline \multicolumn{2}{|l|}{ Male } & 17 & $80.95 \%$ \\
\hline \multicolumn{2}{|c|}{ Female } & 4 & $19.04 \%$ \\
\hline \multicolumn{4}{|c|}{ Type of tumor } \\
\hline & Malignant of the thoracic wall & 9 & $42.85 \%$ \\
\hline- & Benign of the thoracic wall & 2 & $9.52 \%$ \\
\hline- & Pulmonary malignant & 7 & $33.33 \%$ \\
\hline- & Metastasis & 3 & $14.28 \%$ \\
\hline \multicolumn{4}{|c|}{ Number of ribs removed } \\
\hline- & 4 & 8 & $38.09 \%$ \\
\hline- & 5 & 9 & $42.85 \%$ \\
\hline- & 6 & 4 & $19.04 \%$ \\
\hline \multicolumn{2}{|c|}{ Total cases } & 21 & \\
\hline
\end{tabular}

Table 1

CLINICAL-PATHOLOGICAL CHARACTERISTICS OF PATIENTS INCLUDED IN THE STUDY

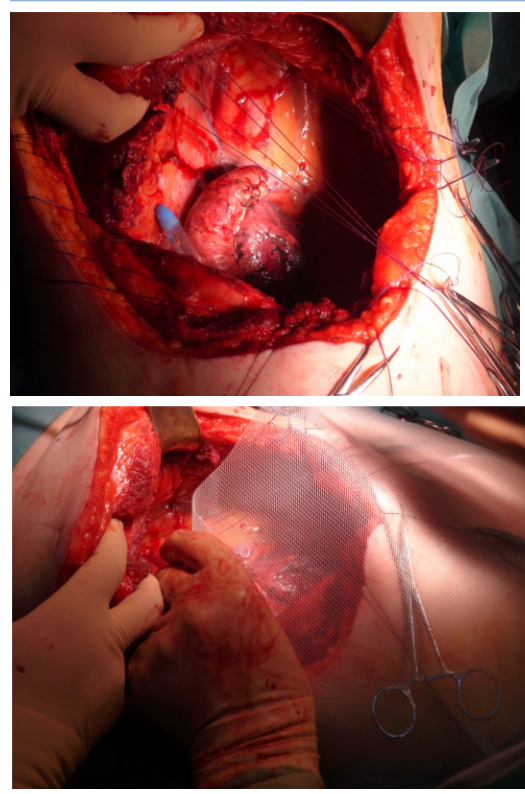

Fig. 1. Positioning of the transfixant vicryl at the level of the intercostal spaces

Fig. 2. Fixing the polypropylene mesh at the level of the thoracic wall

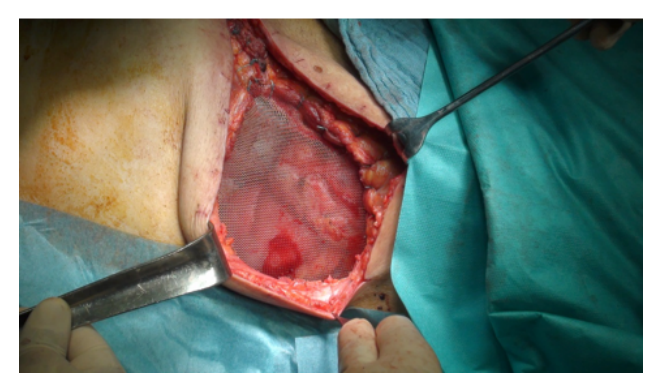

Fig. 3. The final view of the thoracic wall with the polypropylene mesh

surgically treated by necrectomy, wound debridement and antibiotic treatment according to the antimicrobial susceptibility tests. Of the 7 patients who had paradoxical movements of the chest wall, 5 patients experienced respiratory failure. These patients were ventilated mechanically for a period of 3 to 7 days. Out of these patients, none died, all were discharged from the hospital without respiratory failure.

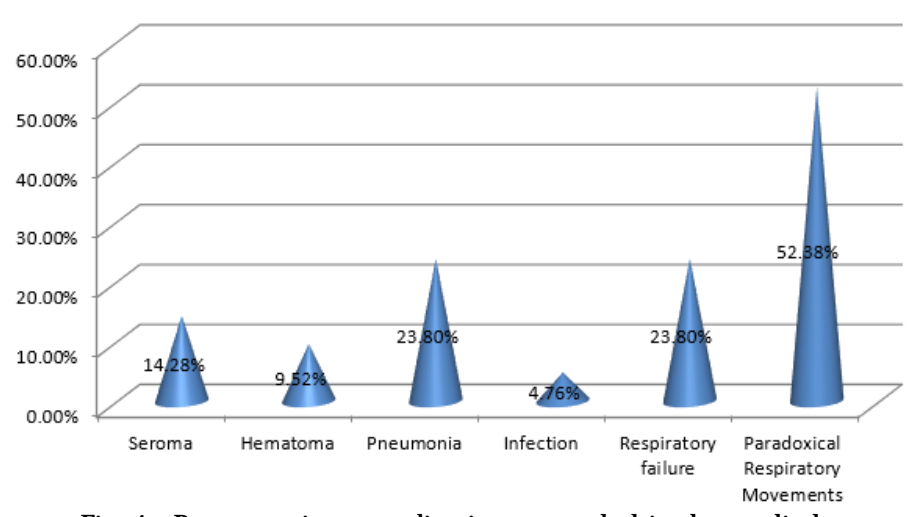

Fig. 4. Postoperative complications recorded in the studied group

\section{Results and discussions}

A particularly important role in thoracic wall surgery, after the resection steps of the chest wall, is the reconstruction technique. The main objectives of such surgical interventions are to obtain a stable thoracic wall that provides adequate protection to the intrathoracic viscera as well as a physiological breathing as close to normal as possible, while avoiding the occurrence of paradoxical respiratory movements at this level [7]. At the same time, the aesthetic aspect of the reconstruction of the thoracic wall has a particularly important role since it is known that thoracic deformities over time can lead to severe respiratory disturbances in these patients [8]. In this regard, it is known that patients with a history of thoracic wall resections have a higher risk of developing scoliosis in time [9].

Mostcommonly, thoracic wall resections are performed for malignant tumors. In these cases it is particularly important to perform a surgical resection for oncological purposes that minimizes the chance of a tumor relapse. In these cases large parietal defects may result $[10,11]$. It has also been demonstrated that the greater the thoracic parietal defect, the greater the chance for the patient to experience postoperative respiratory failure and postoperative complications. This is especially noticeable in patients with more than 4 ribs resected. [12]

Regarding the indications of the thoracic wall reconstruction after thoracic parietal resections, most 
authors recommend that in the case of anterolateral thoracic defects with a size larger than $5 \mathrm{~cm}$ or if more than 4 ribs were resectef, the use of a reconstruction technique of the thoracic wall is mandatory. This is necessary to prevent the hernia of the lung, respiratory insufficiency, and the instability of the thoracic wall. In case of posterior thoracic wall defects, even in large dimensions, this is not necessary because in these cases, the presence of the scapula, as well as a well-represented chest muscles, prevents these incidents [13,14].

Regarding the type of material used in chest wall reconstruction techniques, there are currently controversies about the best material usable. Biological, plastic or metallic materials may be used. Each of them has its advantages and disadvantages [15]. It is considered that materials used in thoracic wall reconstruction techniques should be easy to use, resistant, and more resistant to infection [16]. Generally, due to the fact that the chest wall is well vascularized, heterologous materials are well tolerated at this level [17].

The most common biological materials used in chest wall reconstruction techniques are muscular flaps or musculoskeletal flaps. They have the advantage of being well tolerated by the body but have the disadvantage that sometimes they can not be used in large-scale thoracic defects and require microsurgery techniques for their use. A major advantage of using muscle flaps is that the muscular flap integrates very well into the tissues, and in case of preserving the vasculature, the patient does not experience rejection phenomena. Most commonly used is the latissimus dorsi muscle $[18,19]$. Large pectoral muscles, serratus muscle or rectus abdominis abdominal muscles can also be used. Some authors have used techniques for the reconstruction of the thoracic wall and the large omentum [20, 21].

Initially, the metal plates were used in the reconstruction techniques of the thoracic wall. In the lastdecades titanium is used as metallic material in the techniques of reconstruction of the thoracic wall. Titanium has the advantage of having increased corrosion resistance, low molecular weight and a particularly high traction strength. It also has the advantage of allowing magnetic resonance imaging scabs to be done in these patients, knowing that it is impossible for other metallic materials [5]. Titanium sheets also have the advantage of integrating well on bone surfaces, without the danger of detachment over time $[22,23]$.

Another material used in thoracic wall reconstruction techniques is methyl-methacrylate. The substance is prepared in the operating room and in the thoracic wall reconstruction techniques and is used by interposing polypropylene meshes when they come in contact with the tissues of the patient. An exothermic reaction occurs and the material becomes rigid $[24,25]$. The disadvantage of methacrylate is that, being not permeable to fluids, and being very rigid, patients may experience chronic pain and extensive stiffness of the chest wall [26].

A different variant often used in thoracic wall reconstruction techniques are PTFE (polytetrafluoroethylene) meshes (Gore-Tex). It presents the advantage of having a fairly high resistance whiteouthaving the rigidity of the titanium or methyl-methacrylate plates $[27,28]$. A major advantage of Gore-tex meshes is their impermeability to liquids and air. [29] They also produce a fairly low periprotective inflammatory response compared to the use of other types of materials in thoracic wall reconstructions [30].
Lately, some authors have described the use of polypropylene meshes in thoracic wall reconstruction techniques [31]. Originally, polypropylene meshes were used in the surgical treatment of inguinal hernia or postoperative eventration. The major advantage of polypropylene is that it allows for a very good tissue integration with reduced periprotective inflammatory responses [32,33]. This fact was also observed in our study, with only one patient presenting post-operative signs of infection at the site of implantation of the meshes.

\section{Conclusions}

The use of polypropylene meshes in thoracic wall reconstruction techniques after thoracic wall resections is a viable method, with good respiratory functional results.

\section{References}

1.WEYANT MJ., BAINS MS., VENKATRAMAN E., DOWNEY RJ ., PARK BJ ., FLORES RM., RIZK M., RUSCH RW., Ann. Thorac. Surg., 81,2006,nr. 1,p.279-285

2.SUCIU BA., PAP Z., DENES L., BRINZANIUC K., COPOTOIU C., PAVAI Z., Rom. J. Morphol. Embryol., 57,2016,nr.2,p.495-500

3.BERTHET J P., SOLOVEI L., TIFFET O., GOMEZ-CARO A., BOMMART S., CANAUD L., ALRIC P., MARTY-ANE CH., Eur. J. Cardiothorac. Surg., 44,(2013),nr.5, p.866-871

4.BERTHET JP., WILHM JM., CANAUD L., JOYEUX F., COSMA C., HIRECHE K., ALRIC P., MARTY-ANE CH., Eur. J. Cardiothorac. Surg., 42,2012,nr.3,p.444-453

5.DE PALMA A., SOLLITTO F., LOIZZI D., DI GENNARO F., SCARASCIA D., CARLUCCI A., GIUDICE G., ARMENIO A., LUDOVICO R., LOIZZI M., J. Thorac. Dis., 8,2016, nr.3, p.490-498

6.VASILE. D., IANCU. G., IANCU. RC., DAVITOIU. DV., Mat. Plast,,54, no. 2, 2017, p.229

7.SANNA S., BRANDOLINI J ., PARDOLESSI A., ARGNANI D., MENGOZZI M., DELL'AMORE A., SOLLI P., J. Vis. Surg., 26,2017,nr.3,p.95,

8.TUKIAINEN E., POPOV P., ASKO-SELIAVAARA S., Ann. Surg., 238,2003,nr.6,p.794-801

9.BILLE A., GISABELLA M., ERRICO L., BORASIO P., Interact. Cardiovasc. Thorac. Surg., 12,2011,nr.2,p.293-296

10.MCAFEE MK., PAILORELOR PC., BERGSTRALH EJ., PIEHLER J M., UNNI KK., MCLEOD RA., BERNATZ PE., PAYNE WS., Ann. Thorac. Surg. 40,1985,nr.6, p.535-541

11.DAIGELER A., DRUECKE D., HAKIMI M., DUCHNA HW., GOERTZO., HOMANN HH., LEHNHARDT M., STEINAU HU., Langenbecks Arch. Surg., 394,2009,nr.4, p.705-715

12.GEISSEN NM., MEDAIROS R., DAVILA E., BASU S., WARREN WH., CHMIELEW SKI GW., LIPTAY MJ ., ARNDT AT., SEDER CW., Lung, $194,2016, n r .4, p .619-624$

13.FERRARO P., CUGNO S., LIBERMAN M., DANINO MA., HARRIS PG., Thorac. Surg. Clin., 20,2010,nr. 4, p. 465-473

14.ROCCO G., Semin. Thorac. Cardiovasc. Surg., 23,2011,nr.4,p.307313

15.DESCHAMPS C., TIRKNAKSIZ BM., DARBANDI R., TRASTEK VF., ALLEN MS., MILLER DL., ARNOLD PG., PAIROLERO PC., J. Thorac. Cardiovasc. Surg., 117,1999, nr.3, p.588-591

16.CHEN C., HUANG X., CHEN M., YU F., YIN B., YUAN Y., J. Cardiothorac. Surg., 28,2015,nr.10, p.178

17.BUD V., SUCIU BA., BUTIURCA V., BRINZANIUC K., COPOTOIU R., COPOTOIU C., SIN A., Rom. J. Morphol. Embryol., 54,2013,nr.1,p.115119

18.HAMEED A., AKHTAR S., NAQVI A., PERVAIZZ., J. Plast. Reconstruc. Aesthet. Surg., 61,2008,nr.6,p.628-635

19.ABOLHODA A., WIRTH GA., BUI TD., MILLIKEN JC., Eur. J. Cardiothorac. Surg., 33,2008,nr.5,p.928-930

20.EISHIEKH MA., LO TT., SHIPOLINI AR., MCCORMACK DJ ., Interact. Cardiovasc. Thorac. Surg., 16,2013,nr.1,p.60-67 
21.GONFFIOTI A., SANTINI PF., CAMPANACCI D., INNOCENTI M., FERRARELLO S., CARDARELLA A., JANNI A., Eur. J. Cardiothorac. Surg., 38,2010,nr.1,p.39-45

22.CONNAR AS., QURESHI N., SMITH I., WELLS FC., REISBERG E., WHILM J M., Ann. Thorac. Surg. , 87,2009,nr.5, p.e46-e48

23.WESTPHAL FL., LIMA LC., LIMA NETTO JC., SEELIG SDA C., LIMA KF., J. Bras. Pneumol., 40,2014,nr.2, p.200-202

24.MCCORMACK P., BAINS MS., BEATTIE EJ JR., MARTINI M., Ann. Thorac. Surg., 31,1981,nr.1, p.45-52

25.LARDINOID D., MULLER M., FURRER M., BANIC A., GUGGER M., KRUEGER T., RIS HB., Ann. Thorac. Surg., 69,2000,nr.3,p.919-923 26.SEDER CW., ROCCO G., J. Thorac. Dis., 8,2016,nr.11,p.S863-871 27.MACEDO-NETO AV., SANTOS LV., MENEZES SL., PAIVA DS., ROCCO PR., ZIN WA., Chest, 113,1998,nr.6,p.1667-1672
28.LEUZZI G., NACHIRA D., CESARIO A., NOVELLIS P., PETRACCA CIAVARELLA L., LOCOCO F., FACCIOLO F., GRANONE P., MARGARITORA S., Thorac. Cancer., 6,2015,nr.3,p.246-254

29.LE ROUX BT., SHAMA DM., Curr. Probl. Surg., 20,1983,nr.6,p.345386

30.HUANG H., KITANO K., NAGAYAMA K., NITADORI J., ANRAKU M., MURAKAWA T., NAKAJIMA J ., Ann. Thorac. Cardiovasc. Surg., 21,2015,nr.2,p.119-124

31.KAWANA S., YAMAMOTO H., MAKI Y., SUGIMOTO S., TOYOOKA S., MIYOSHI S., Acta. Med. Okayama., 71,2017,nr.3,p.259-262

32.BRATU, D., BOICEAN, A., TANASESCU, C., SOFARIU, C., MIHETIU, A., CERNUSCA MITARIU, I.S., OGNEAN, L., MOLDOVAN, C., BOITOR, C., Mat. Plast., 54, 2017, no.1, p.119

33.SUCIU, BA., HALMACIU, I., BUD, V., COPOTOIU, C., FODOR, DRP., TRAMBITAS, C., VUNVULEA, V., MOLNAR, C., BRINZANIUC, K., Mat. Plast., 54, 2017, no.3, p.520

Manuscript received: 26.07 .2017 